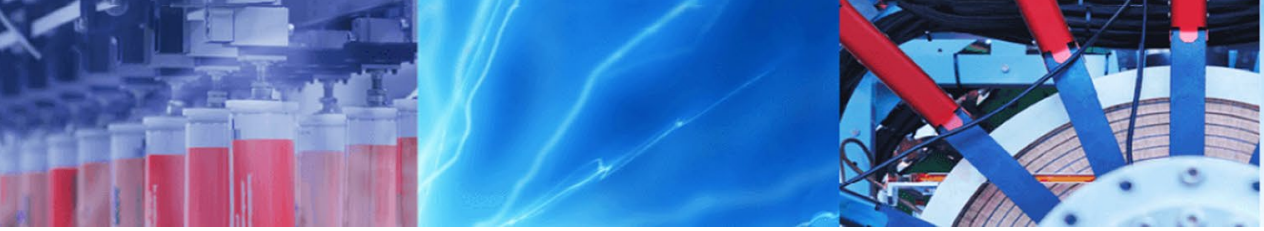

Research Article

\title{
Removal of humic acid from aqueous solutions by a novel hydrogarnet/zeolite composite
}

\author{
Hirotaka Maeda ${ }^{1}$ (1) $\cdot$ Kazuya Suzumura ${ }^{1} \cdot$ Toshihiro Kasuga $^{1}$
}

Received: 1 June 2020 / Accepted: 24 September 2020 / Published online: 3 October 2020

(c) Springer Nature Switzerland AG 2020

\begin{abstract}
Removal of humic acid from aqueous solutions is pivotal to protect water from environmental and health concerns. Slurry consisting of silica gel, alumina, calcium hydroxide, and zeolite A was hydrothermally treated to prepare a hydrogarnet/ zeolite composite for humic acid removal from water. The amount of hydrogarnet formed and the partial disorder in the zeolite structure affected the porous properties of the composite. The zeolite content in the slurry influenced the humic acid adsorption capacity. The composite hydrothermally treated for $2 \mathrm{~h}$ showed improvement in higher humic acid adsorption capacity $\left(9.0 \mathrm{mg} \mathrm{g}^{-1}\right)$ than the composites hydrothermally treated for 6 and $24 \mathrm{~h}\left(7.4\right.$ and $\left.5.9 \mathrm{mg} \mathrm{g}^{-1}\right)$ based on the pseudo-second-order model. The adsorption capacity of the composite was related to its crystal phase and the lattice distortion of the hydrogarnet, not the amount of hydrogarnet formed.
\end{abstract}

Keywords Humic acid removal $\cdot$ Composite $\cdot$ Hydrothermal $\cdot$ Zeolite $\cdot$ Hydrogarnet

\section{Introduction}

Natural organic matter (NOM) present in water is formed via metabolic reactions and contains mainly humic substances, polysaccharides, and proteins. The contamination level of NOM in water is changed by the site and season [1]. High NOM levels in water can cause coloration and fouling of membranes used in ultrafiltration treatments for drinking water [2-5]. Removal of NOM from aqueous solutions by using adsorbents and coagulants $[6,7]$ is important, addressing aesthetic and health concerns. Many adsorbent types were reported to purify water containing humic acid (HA), which is one constituent of humic substances present in water [8,9]. Zeolite-based materials are known to be HA adsorbents [10]. It was reported that a combination of zeolite with chitosan, cetylpyridinium bromide hydrate, and $\mathrm{N}, \mathrm{N}$-dimethyl dehydroabietylamine oxide has improved HA adsorption capacity due to hydrophobic interactions and hydrogen bonds [11-13]. Using such a zeolite composite is a suitable approach to remove color resulting from the presence of NOM in water.

Hydrogarnet $\left(\mathrm{Ca}_{3} \mathrm{Al}_{2}\left(\mathrm{SiO}_{4}\right)_{3-x}(\mathrm{OH})_{4 x}\right.$ with $\left.x=0-3\right)$ prepared by a hydrothermal treatment is a solid solution consisting of $\mathrm{Ca}_{3} \mathrm{Al}_{2}(\mathrm{OH})_{12}$ and $\mathrm{Ca}_{3} \mathrm{Al}_{2}\left(\mathrm{SiO}_{4}\right)_{3}$. It is a novel $\mathrm{HA}$ adsorbent that utilizes hydroxyl groups at the surface to interact with HA [14]. Zeolite dealumination is achieved by hydrothermal treatment and leads to an increase in the number of $\mathrm{SiOH}$ [15]. This supposes that a combination of hydrogarnet with zeolite by a hydrothermal treatment is one approach to provide HA adsorption sites, increasing its adsorption properties. In this study, composites were hydrothermally prepared by combining zeolites and hydrogarnet, and the HA adsorption abilities of the resulting composites were evaluated to

Electronic supplementary material The online version of this article (https://doi.org/10.1007/s42452-020-03590-5) contains supplementary material, which is available to authorized users.

Hirotaka Maeda, maeda.hirotaka@nitech.ac.jp | 1 Department of Life Science and Applied Chemistry, Nagoya Institute of Technology, Gokiso-cho, Showa-ku, Nagoya 466-8555, Japan. 
investigate a new materials design for NOM removal applications.

\section{Materials and and methods}

Calcium hydroxide $\left(\mathrm{Ca}(\mathrm{OH})_{2}\right)$, $\gamma$-alumina $\left(\mathrm{Al}_{2} \mathrm{O}_{3}\right.$, Taimei Chemicals Co. Ltd.), and silica gel ( $\mathrm{SiO}_{2}$, Fuji Silysia Chemical Ltd.) powders were used as starting materials to prepare the hydrogarnet and mixed in a $\mathrm{Ca} / \mathrm{Al} / \mathrm{Si}$ molar ratio of 3:2:1. Calcium hydroxide was prepared by adding distilled water to calcium oxide obtained by heattreating calcium carbonate at $1000^{\circ} \mathrm{C}$ for $3 \mathrm{~h}\left(\mathrm{CaCO}_{3}\right.$, Fujifilm Wako Pure Chemical Corp.). Zeolite A with a Si/ $\mathrm{Al}=1$ (Synthetic A-3, Fujifilm Wako Pure Chemical Corp.) was used because the Gibbs free energy of formation for zeolite A [16] is more unstable compared to that of the hydrogarnet [17]. The zeolite was added to achieve a zeolite/mixture ratio of $30 / 70$ or $70 / 30$ by weight to determine the main phase of the composite. Then, distilled water was added to prepare the slurry with a solid/ liquid ratio of $1 / 10$. The slurry was stirred and hydrothermally treated at $150^{\circ} \mathrm{C}$ between 1 and $24 \mathrm{~h}$. The deposit obtained after filtration was dried at $80^{\circ} \mathrm{C}$ for $12 \mathrm{~h}$, which is the flowchart of this process as shown in SM1.

The crystal phases of the composites were analyzed by X-ray diffraction (XRD) with a $0.015^{\circ} / \mathrm{s}$ scanning rate using a semiquantitative technique with silicon as the internal standard. The morphology of the composites was observed by field-emission scanning electron microscopy (FE-SEM) with an accelerating voltage of $5 \mathrm{kV}$ and a working distance of $8 \mathrm{~mm}$. Hydroxyl groups of the composites were evaluated by Fourier transform infrared (FT-IR) spectroscopy. The porous properties of the composites were measured using nitrogen gas adsorption analysis at $-196{ }^{\circ} \mathrm{C}$. The specific surface area and mesopore volume were determined using the Brunauer-Emmett-Teller and Cranston-Inkley methods, respectively $[18,19]$. Before the analysis, the composites were heated at $150^{\circ} \mathrm{C}$ under vacuum for at least $3 \mathrm{~h}$. The zeta potentials of the composites at $\mathrm{pH} 7$ (adjusted by $0.1 \mathrm{M} \mathrm{NaOH}$ and $\mathrm{HCl}$ ) were analyzed using a laser Doppler velocimeter. HA adsorption tests were performed per batch with a solid/liquid ratio of $50 \mathrm{mg} / 20 \mathrm{~mL}$ using a HA solution with an initial concentration of $30 \mathrm{ppm}$, shaking the solution at $100 \mathrm{rpm}$ and $25^{\circ} \mathrm{C}$. The supernatant obtained after the centrifugation of the test solution was analyzed in triplicate using a multimode plate reader and a 96-well UV transparent microplate, monitoring the change in absorbance at $365 \mathrm{~nm}$. The absorbance of the blank sample was measured for each adsorption test as reference.

\section{Results and discussion}

The peaks corresponding to the hydrogarnet, zeolite, and calcium hydroxide were observed in the composites obtained by hydrothermal treatment for $6 \mathrm{~h}$, independent of the weight ratio of the slurries, as shown in Fig. 1. The composites prepared using slurries containing 30 and $70 \mathrm{wt} \%$ zeolite had specific surface areas of 120 and $45 \mathrm{~m}^{2} \mathrm{~g}^{-1}$, respectively, and adsorbed $8.8 \pm 0.7$ and $1.5 \pm 0.1 \mathrm{mg} \mathrm{g}^{-1}$ of HA, respectively, after $24 \mathrm{~h}$. Pure zeolite $A$, on the other hand, provided almost no HA adsorption at the same conditions. Therefore, the combination of hydrogarnet with zeolite $A$ indicated a potential for $\mathrm{HA}$ adsorbent applications. The HA adsorption properties of the composite prepared from slurry containing $30 \mathrm{wt} \%$ zeolite were investigated.

Figure 2a shows the XRD patterns of the composites after hydrothermal treatment. Even after $1 \mathrm{~h}$, peaks corresponding to the hydrogarnet are observed in the XRD patterns in addition to those related to calcite and the $\mathrm{C}-\mathrm{S}-\mathrm{H}$ gel, which were produced as by-products. The peaks corresponding to pure zeolite $A$ decreased in intensity with time and disappeared after $6 \mathrm{~h}$ of treatment, as

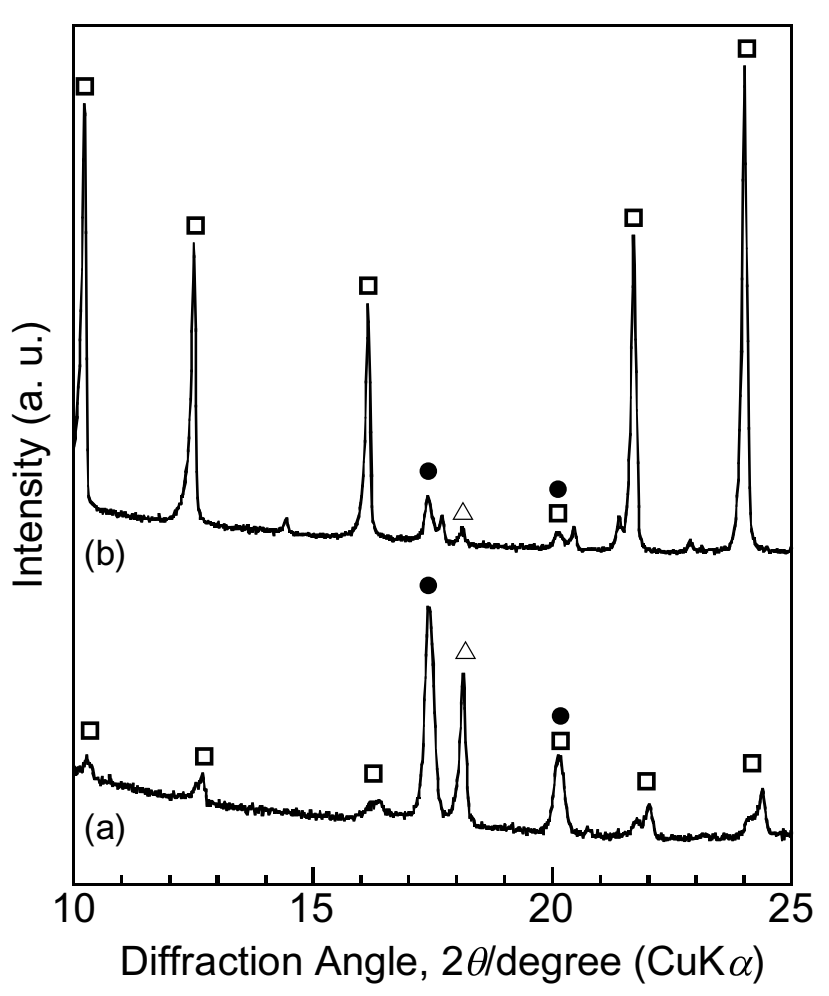

Fig. 1 XRD patterns of the composites hydrothermally prepared for $6 \mathrm{~h}$ using slurries containing (a) 30 or (b) 70 wt\% zeolite after the hydrothermal treatment. (square) zeolite $A$, (filled circle) hydrogarnet, (triangle) calcium hydroxide 
(a)

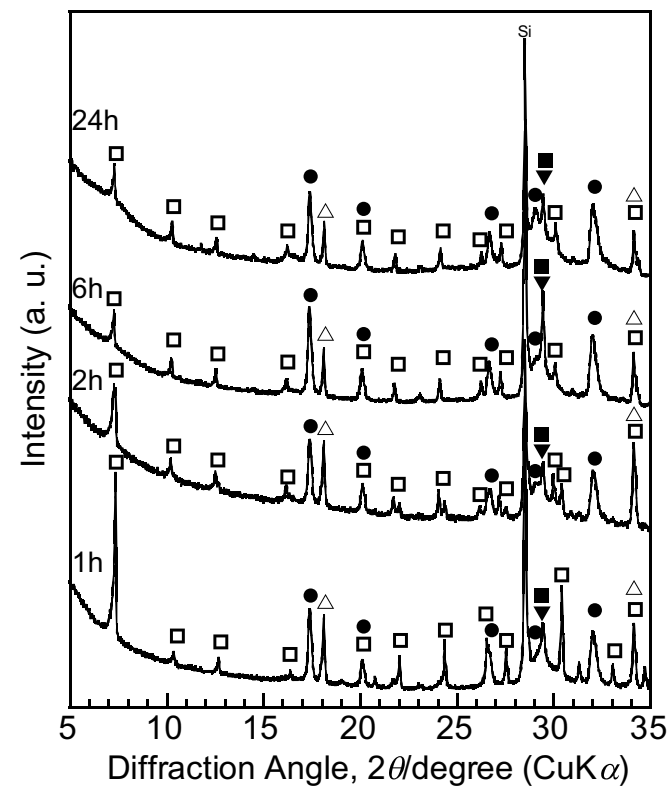

Fig. 2 a XRD patterns of the composites after hydrothermal treatment. b Relationships between the $I_{\text {hydrogarnet }} / I_{\mathrm{si}}$ ratio and $I_{\text {zeolite }} / I_{\mathrm{si}}$ ratio with the hydrothermal treatment time. (square) zeolite $A$,

shown in Fig. SM2. In addition, the peaks at a lower diffraction angle corresponding to zeolite $A$ appeared after $2 \mathrm{~h}$. There was almost no change in the peaks of the XRD pattern when pure zeolite $A$ was hydrothermally treated at $150^{\circ} \mathrm{C}$ for $6 \mathrm{~h}$, as shown in Fig. SM3. A local disorder in the mordenite structure was observed after soaking it in hot sodium hydroxide solution due to an incongruous dissolution, resulting in a slight change in the XRD pattern [20]. The dissolution of calcium hydroxide produced alkaline conditions during the hydrothermal treatment, creating a local disorder in the zeolite A structure and changing its corresponding XRD peaks. The amount of zeolite A and hydrogarnet in the composites was determined in terms of $I_{\text {zeolite }} / I_{\text {si }}$ and $I_{\text {hydrogarnet }} / l_{\text {si }}$, respectively (Fig. $2 \mathrm{~b}$ ), where $I_{\text {zeolite }} I_{\text {hydrogarnet }}$ and $I_{\text {si }}$ denote the integrals of the zeolite $A$ peak at approximately $7^{\circ}(100)$, the hydrogarnet peak at approximately $32^{\circ}(422)$, and the silicon peak at approximately $28^{\circ}(111)$, respectively. The integrals were fitted using Lorentzian functions. The zeolite content in the composites stabilized after $2 \mathrm{~h}$ of treatment and decreased dramatically after $6 \mathrm{~h}$, subsequently increasing only slightly. The hydrothermal zeolite synthesis is a reaction-crystallization process, in which amorphous reactants are converted to a crystalline product through hydroxyl ions [21]. It is suggested that zeolite A partially dissolved and simultaneously formed an amorphous phase as a precursor at the initial stage of the treatment, and then recrystallized under alkaline conditions. On the (b)

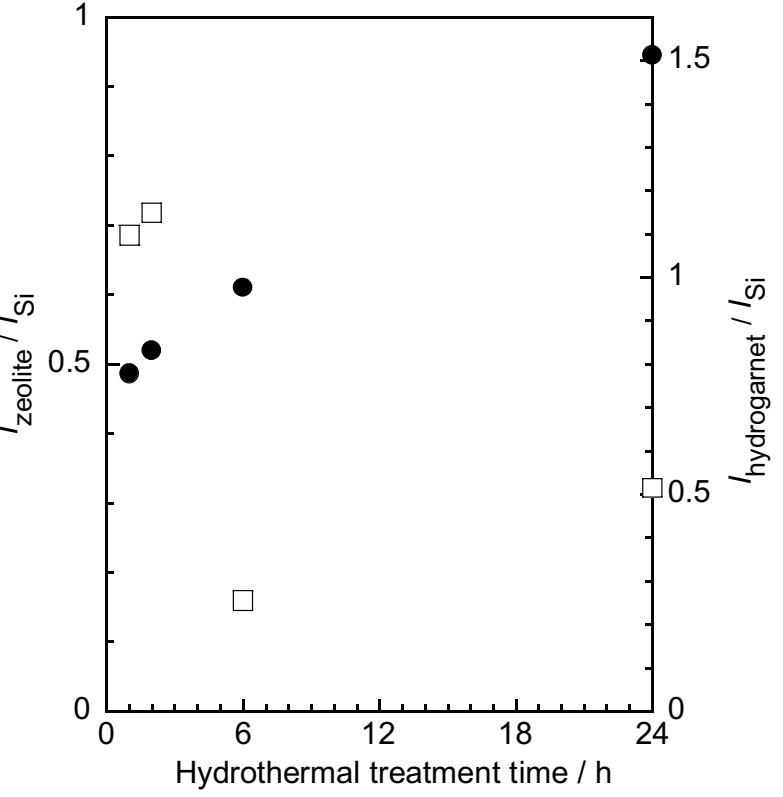

(filled circle) hydrogarnet, (triangle) calcium hydroxide, (filled inverted triangle) $\mathrm{C}-\mathrm{S}-\mathrm{H}$ gel, (filled square) calcite, (Si) internal standard material

other hand, the hydrogarnet content in the composites increased with time. The changes in the composite morphologies after the treatment are shown in Fig. 3. Zeolite $A$ is a cubic-shaped crystal and formed particle aggregate sizes of 2 to $5 \mu \mathrm{m}$ (Fig. 3e). There was almost no change in morphology when the pure zeolite was hydrothermally treated at $150^{\circ} \mathrm{C}$ for $6 \mathrm{~h}$ (Fig. 3f). It was observed that the surfaces of the zeolite $A$ particles were covered with deposits even after $1 \mathrm{~h}$ of treatment. There were hardly any cubic and petal or lath-like morphologies of calcite and $\mathrm{C}-\mathrm{S}-\mathrm{H}$ gel observed in these SEM micrographs. Based on the XRD results, the spaces between zeolite $A$ particles in their aggregates decreased with increasing treatment time. This can be due to the settling of newly formed deposits such as hydrogarnet. There was almost no change in the absorbance at around $3600-3700 \mathrm{~cm}^{-1}$ due to hydroxyl groups of the FT-IR spectra of the composites, as shown in SM4. Each composite provided a similar zeta potential (approximately $-13 \mathrm{mV}$ ) at $\mathrm{pH}=7$. These seem that the composites have almost the same condition as the hydroxyl groups.

Figure 4 shows the variations in the specific surface area and the mesopore volume of the composites with hydrothermal treatment time. Zeolite A exhibited a relatively low specific surface area of approximately $1 \mathrm{~m}^{2} \mathrm{~g}^{-1}$ and a mesopore volume of approximately $0.006 \mathrm{~cm}^{3} \mathrm{~g}^{-1}$. The mesopore volume of the composites increased sharply to approximately $1.0 \mathrm{~cm}^{3} \mathrm{~g}^{-1}$ after $6 \mathrm{~h}$ and then increased 

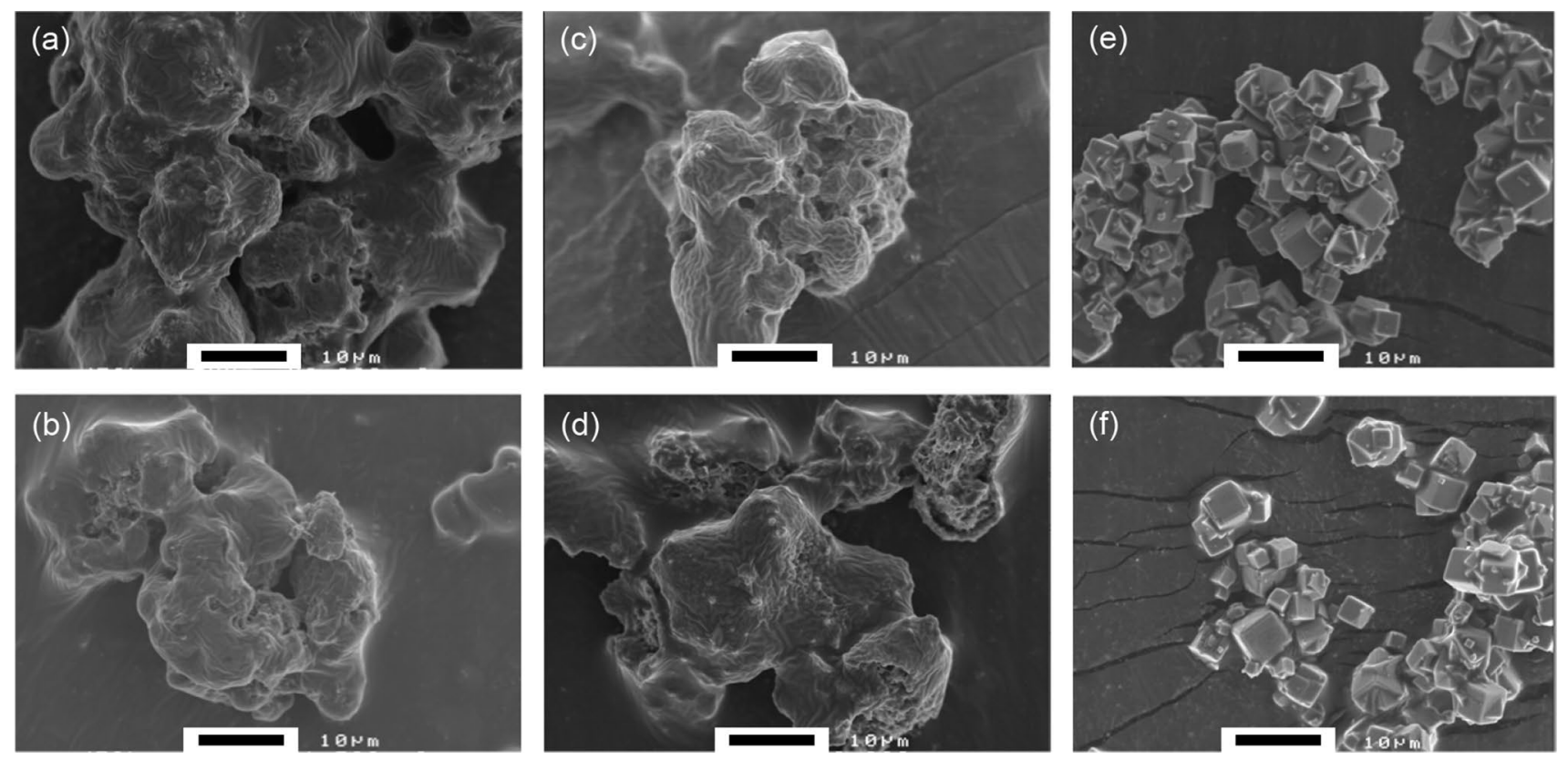

Fig. 3 SEM micrographs of the composites after a 1 h, b 2 h, c 6 h, and $\mathbf{d} 24 \mathrm{~h}$, and zeolite A e before and f after $6 \mathrm{~h}$ of the hydrothermal treatment. The scale bar shows $10 \mu \mathrm{m}$

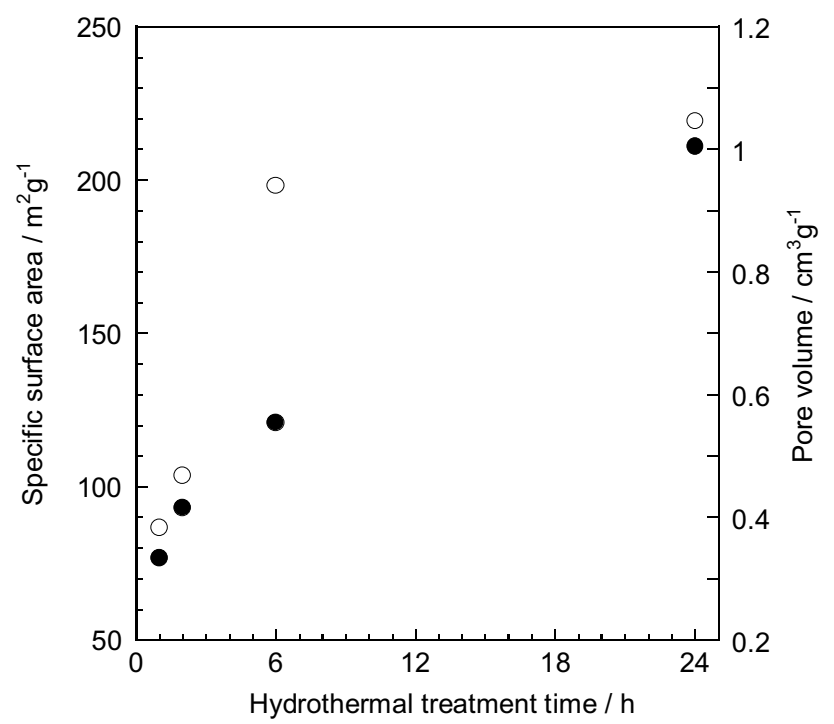

Fig. 4 Variation of (filled circle) specific surface area and (circle) mesopore volume of the composites with the hydrothermal treatment time

slightly further. On the other hand, the specific surface area of the composites increased to approximately $210 \mathrm{~m}^{2}$ $\mathrm{g}^{-1}$ with treatment time. It is known that treating zeolite with alkali forms mesopores [22, 23]. The dealumination of the zeolite framework creates a secondary network of mesopores in the zeolite crystals [24]. The dissolution process is promoted, but the adsorption process is hampered after the mesopore formation [25]. This implies that the dissolution of zeolite $A$ at alkaline conditions created mesopores in the composites and the recrystallization $24 \mathrm{~h}$ after the treatment suppressed the further increase in the mesopore volume of the composites. The amount of hydrogarnet in the composites increased with treatment time. The specific surface area of the composites increased due to the formation of mesopores derived from the zeolite dissolution and the formed hydrogarnet.

Adsorption kinetics were measured to determine the HA adsorption properties of the composites, as shown in Fig. 5a. The composite hydrothermally treated for $2 \mathrm{~h}$ exhibited the highest HA adsorption capacity among the composites. The correlation coefficients $(>0.99)$ of the plots for the pseudo-second-order model of the composites were higher than those $(>0.93)$ for the pseudofirst-order model and those $(>0.95)$ for the intraparticle diffusion model, showing that $\mathrm{HA}$ adsorption data better fitted the pseudo-second-order model. The equation is described as follows:

$\frac{t}{q_{\mathrm{t}}}=\frac{1}{k_{2} q_{\mathrm{e}}^{2}}+\frac{1}{q_{\mathrm{e}}} t$

where $q_{\mathrm{e}}$ and $q_{\mathrm{t}}\left(\mathrm{mg} \mathrm{g}^{-1}\right)$ indicate the amount of HA adsorbed at equilibrium and adsorption time, respectively, and $k_{2}\left(\mathrm{~g} \mathrm{mg}^{-1} \mathrm{~h}^{-1}\right)$ is the rate constant of adsorption. The values of $q_{\mathrm{e}}$ and $k_{2}$ listed in Table 1 were calculated using the slope and intercept of the linear plots shown in Fig. $5 \mathrm{~b}$. 
(a)

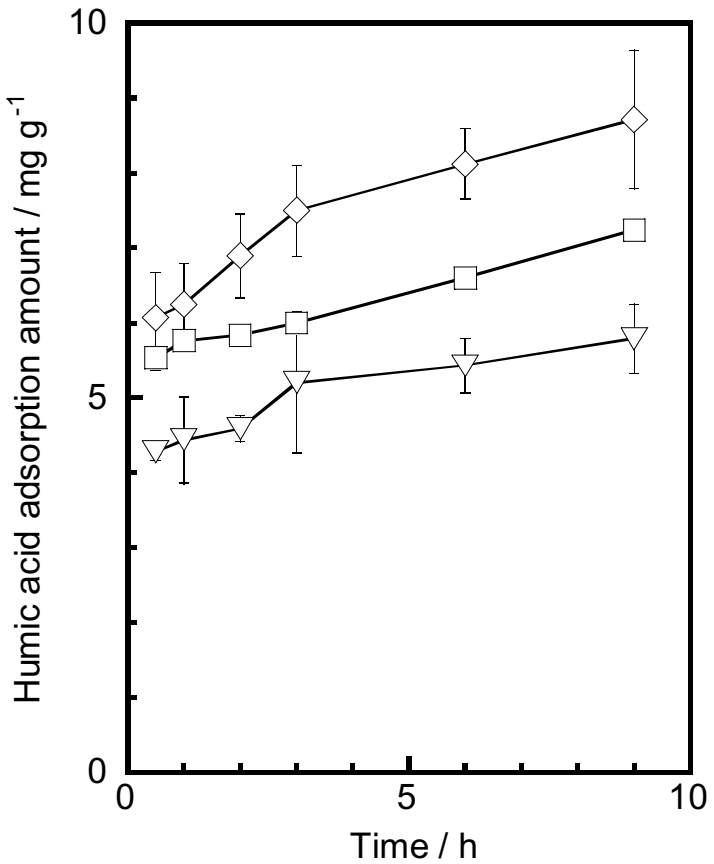

(b)

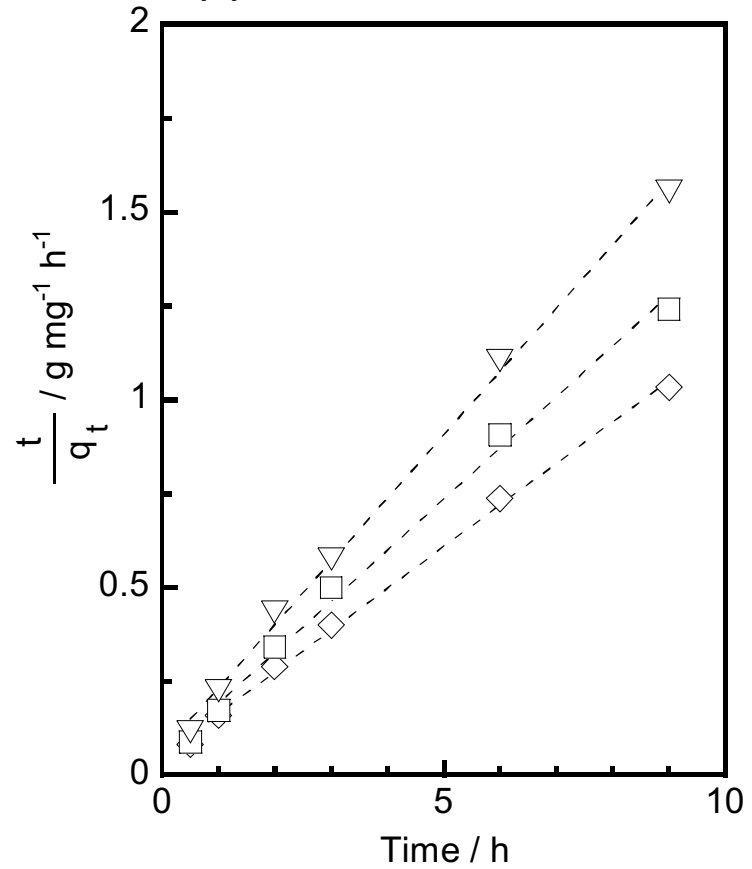

Fig. 5 a Adsorption capacity of HA by the composites. b Pseudo-second-order adsorption kinetics of HA by the composites. The composites were prepared hydrothermally for (diamond) $2 \mathrm{~h}$, (square) $6 \mathrm{~h}$, and (inverted triangle) $24 \mathrm{~h}$

Table 1 Pseudo-second-order constants $q_{\mathrm{e}}$ and $k_{2}$ of the composites after $\mathrm{HA}$ adsorption tests

\begin{tabular}{|c|c|c|}
\hline & $q_{\mathrm{e}}\left(\mathrm{mg} \mathrm{g}^{-1}\right)$ & $\begin{array}{l}k_{2}\left(\times 10^{-1}\right. \\
\mathrm{g} \mathrm{mg}^{-1} \\
\left.\mathrm{~h}^{-1}\right)\end{array}$ \\
\hline Composite hydrothermally treated for $2 \mathrm{~h}$ & 9.0 & 2.3 \\
\hline Composite hydrothermally treated for $6 \mathrm{~h}$ & 7.4 & 3.3 \\
\hline $\begin{array}{l}\text { Composite hydrothermally treated for } \\
24 \mathrm{~h}\end{array}$ & 5.9 & 4.3 \\
\hline
\end{tabular}

It seems that the hydroxyl groups of the composites have little effect on the HA adsorption capacity by considering the FT-IR spectra and their zeta potentials. The pure zeolite A before and after $6 \mathrm{~h}$ of hydrothermal treatment at $150^{\circ} \mathrm{C}$ indicated hardly any $\mathrm{HA}$ adsorption even after $24 \mathrm{~h}$. The hydrogarnet prepared by hydrothermally treating slurry of calcium hydroxide, $\gamma$-alumina, and silica gel with distilled water as the solvent for $6 \mathrm{~h}$ showed $q_{\mathrm{e}}$ and $k_{2}$ values of $11.1 \mathrm{mg} \mathrm{g}^{-1}$ and $4.7 \times 10^{-2} \mathrm{~g} \mathrm{mg}^{-1} \mathrm{~h}^{-1}$, respectively [14], which means it has slightly larger $\mathrm{HA}$ adsorption capacity and much lower rate constant of adsorption than the composite hydrothermally treated for $2 \mathrm{~h}$. We assumed that calcite and the $\mathrm{C}-\mathrm{S}-\mathrm{H}$ gel barely affected the HA adsorption capacity due to their trace amounts in the composites. The amount of $\mathrm{Ca}(\mathrm{OH})_{2}$ in the composites was determined in terms of $I_{\mathrm{Ca}(\mathrm{OH}) 2} / I_{\mathrm{si}}$, where $I_{\mathrm{Ca}(\mathrm{OH}) 2}$ denotes the integrals of the $\mathrm{Ca}(\mathrm{OH})_{2}$ peak at approximately $18^{\circ}(001)$. The $\mathrm{Ca}(\mathrm{OH})_{2}$ contents in the composites after 2,6 , and $24 \mathrm{~h}$ of the treatment were $0.50,0.17$, and 0.24 , respectively. This implies that $\mathrm{Ca}(\mathrm{OH})_{2}$ content in the composites has little effect on the HA adsorption capacity under this experimental condition. These suppose that the hydrogarnet in the composite played an important factor with respect to the HA adsorption capacity.

Controlling the chemical composition of the hydrogarnet enhanced the HA adsorption properties [14]. All the composites had a similar chemical composition $\left(\mathrm{Ca}_{3} \mathrm{Al}_{2}\left(\mathrm{SiO}_{4}\right)_{0.4}(\mathrm{OH})_{10.4}\right)$ which was established from the XRD patterns [26]. Although the hydrogarnet content in the composite increased, the $q_{\mathrm{e}}$ value decreased. In the case of $\mathrm{CeO}_{2}-\mathrm{Fe}_{2} \mathrm{O}_{3}$ mixed oxide catalysts, the lattice distortion and the surface iron species were reported to play a crucial role in determining the catalytic activity [27]. We supposed that the lattice distortion of HA may affect the adsorption capacity. The lattice distortions of the hydrogarnets in the composites were determined from the slopes of the Williamson-Hall plots [28] based on the XRD diffractions of the composites (Fig. 6). The hydrogarnet lattice distortions observed after 2,6 , and $24 \mathrm{~h}$ were 0.36 , 0.43 , and 0.62 , respectively, indicating an increase with increasing content in the composites. The lattice distortion obtained by hydrothermally treating slurry consisting of calcium hydroxide, $\gamma$-alumina, silica gel, and distilled 


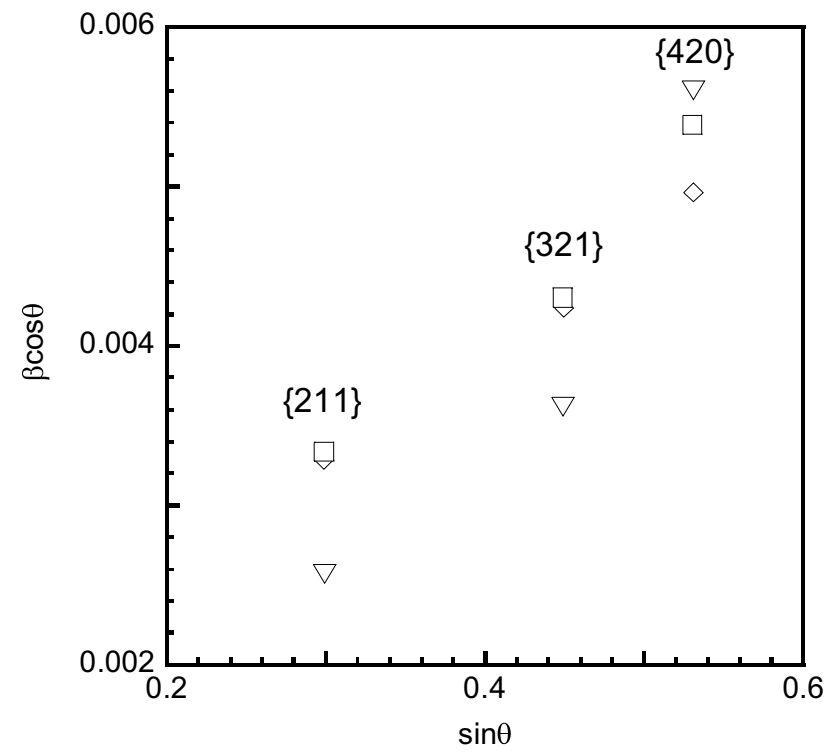

Fig. 6 Williamson-Hall plots for hydrogarnet in the composites hydrothermally prepared at (diamond) $2 \mathrm{~h}$, (square) $6 \mathrm{~h}$, and (inverted triangle) $24 \mathrm{~h}$

water as a solvent for $6 \mathrm{~h}$ was 0.24 . We suppose that the $\mathrm{HA}$ adsorption capacity of the composites is influenced by the lattice disorder of the hydrogarnet under experimental conditions, compared with the hydrogarnet content of the composite. Although the hydrogarnet lattice disorder decreased in composites with zeolite $\mathrm{A}$, a composite hydrothermally treated for $2 \mathrm{~h}$ indicated almost the same HA adsorption capacity than that of the pure hydrogarnet. This implied that various HA adsorption sites at the composite surface were formed due to the presence of different crystal phases such as hydrogarnet, raw zeolite $A$, and zeolite with the locally disordered structure.

The $k_{2}$ values of the composites increased with hydrothermal treatment time. Combining hydrogarnets with zeolites enhanced the HA adsorption rate, compared with the pure hydrogarnet. This suggested that the improved specific surface area of the composites increased the number of $\mathrm{HA}$ adsorption sites at the composite surface, leading to higher adsorption rates. New types of HA adsorbents, such as hybrids and composites, were recently reported [29-31]. The composite that was hydrothermally treated for $2 \mathrm{~h}$ should show similar or even better HA removal efficiency (around 52\%) at $\mathrm{pH}=7$ than ceramicbased materials (22-50\%) at a pH range of 6 and 9 within $1 \mathrm{~h}$ of contact time [32,33], although the adsorption was tested at different conditions. The amount of adsorbent dosage and $\mathrm{pH}$ of the solution is important keys for efficient removal of a water pollutant [34, 35]. To enable a more in-depth discussion on the HA adsorption capacity of the composite, investigations with respect to the effect of the adsorbent mass and the $\mathrm{pH}$, and its cyclic adsorption performance are in progress.

\section{Conclusions}

Hydrogarnet/zeolite A composites were prepared by hydrothermal treatment to improve the color of aqueous solutions containing HA. The hydrothermal treatment time influenced the amounts and crystal structures of the hydrogarnet and the zeolite A in the composites. This, in turn, affected their porosities and HA adsorption properties. The kinetic adsorption experiments fitted well with the pseudo-second-order model which revealed that composite hydrothermally treated for $2 \mathrm{~h}$ had a higher HA adsorption capacity than other composites. The porous properties of the composites increased with increasing hydrothermal treatment time. The composites had the almost identical zeta potential. These seem to be one of the factors for enhancement of the $\mathrm{HA}$ adsorption rate constants. Considering the material design for NOM removal applications, composites consisting of hydrogarnet with a low lattice distortion and zeolite with a partial disorder structure are promising for development of the excellent $\mathrm{HA}$ adsorption properties.

\section{Compliance with ethical standards}

Conflict of interest The authors declare no competing financial interests.

\section{References}

1. Sefa-Ntiri B, Kwakye-Awuah B, Edziah R, Anderson B, Armah FA, Mensah-Amoah P, Sackey SS, Sam F, Akyea AG, Yunus S, Tatchie E, Nkansah BK, Kumi F (2020) Dissolved organic matter in hand-dug well water as groundwater quality indicator: assessment using laser-induced fluorescence spectroscopy and multivariate statistical techniques. SN Appl Sci 2:834. https ://doi.org/10.1007/s42452-020-2446-4

2. Steelink C (1977) Humates and other organic substances in the aquatic environment. J Chem Educ 54:599-603. https://doi. org/10.1021/ed054p599

3. Howe KJ, Clark MM (2002) Fouling of microfiltration and ultrafiltration membranes by natural waters. Environ Sci Technol 36:3571-3576. https://doi.org/10.1021/es025587r

4. Xiao Y, Rohrlack T, Riise G (2020) Unraveling long-term changes in lake color based on optical properties of lake sediment. Sci Total Environ 699:134388. https://doi.org/10.1016/j.scito tenv.2019.134388

5. Werber JR, Osuji CO, Elimelich M (2016) Materials for next-generation desalination and water purification membranes. Nat Rev Mater 1:16018. https://doi.org/10.1038/natrevmats.2016.18

6. Turunen J, Karppinen A, Ihme R (2019) Effectiveness of biopolymer coagulants in agricultural wastewater treatment at two 
contrasting levels of pollution. SN Appl Sci 1:210. https://doi. org/10.1007/s42452-019-0225-x

7. Rucka K, Solipiwko-Pieścik A, Wolska M (2019) Effectiveness of humic substance removal during the coagulation process. SN Appl Sci 1:535. https://doi.org/10.1007/s42452-019-0541-1

8. Chang MY, Juang RS (2004) Adsorption of tannic acid, humic acid, and dyes from water using the composite of chitosan and activated clay. J Colloids Interface Sci 278:18-25. https://doi. org/10.1016/j.jcis.2004.05.029

9. Wang RX, Wen T, Wu XL, Xu AW (2014) Highly efficient removal of humia acid from aqueous solutions by $\mathrm{Mg} / \mathrm{Al}$ layered double hydroxides $-\mathrm{Fe}_{3} \mathrm{O}_{4}$ nanocomposites. RSC Adv 4:21802-21809. https://doi.org/10.1039/C4RA02212B

10. Wang S, Terdkiatburana T, Tadé $M O$ (2008) Adsorption of $\mathrm{Cu}(\mathrm{II})$, $\mathrm{Pb}(\mathrm{II})$ and humic acid on natural zeolite tuff in single and binary systems. Sep Purif Technol 62:64-70. https://doi.org/10.1016/j. seppur.2008.01.004

11. Liu S, Zhang W, Tan X, Zhao F, Huang W, Du H, Goodman BA, Lei F, Diao K (2018) Performance of a zeolite modified with $\mathrm{N}, \mathrm{N}$ dimethyl dehydroabietylamine oxide (DAAO) for adsorption of humic acid assessed in batch and fixed bed columns. RSC Adv 8:9006-9016. https://doi.org/10.1039/C8RA00166A

12. Lin J, Zhan $Y$ (2012) Adsorption of humic acid from aqueous solution onto unmodified and surfactant-modified chitosan/ zeolite composites. Chem Eng J 200-202:202-213. https://doi. org/10.1016/j.cej.2012.06.039

13. Zhan Y, Zhu Z, Lin J, Qiu Y, Zhao J (2010) Removal of humic acid from aqueous solution by cetylpyridinium bromide modified zeolite. J Environ Sci 22:1327-1334. https://doi.org/10.1016/ S1001-0742(09)60258-8

14. Maeda H, Kurosaki Y, Nakayama M, Ishida EH, Kasuga T (2018) Adsorption behaviour of hydrogarnet for humic acid. R Soc Open Sci 5:172023. https://doi.org/10.1098/rsos.172023

15. Janin A, Maache M, Lavalley JC, Joly JF, Raatz F, Szydlowski N (1991) FT-IR study of the silanol groups in dealuminated HY zeolites: Nature of the extraframework debris. Zeolites 11:391-396. https://doi.org/10.1016/0144-2449(91)80308-M

16. Mattigod SV, McGrail BP (1999) Estimating the standard free energy of formation of zeolite using the polymer model. Microporous Mesoporous Mater 27:41-47. https://doi. org/10.1016/S1387-1811(98)00228-5

17. Matschei T, Lothenbach B, Glasser FP (2007) Thermodynamic properties of portland cement hydrates in the system CaO$\mathrm{Al}_{2} \mathrm{O}_{3}-\mathrm{SiO}_{2}-\mathrm{CaSO}_{4}-\mathrm{CaCO}_{3}-\mathrm{H}_{2} \mathrm{O}$. Cem Concr Res 37:1379-1410. https://doi.org/10.1016/j.cemconres.2007.06.002

18. Brunauer S, Emmett PH, Edward E (1938) Adsorption of gases in multimolecular layers. J Am Chem Soc 60:309-319. https://doi. org/10.1021/ja01269a023

19. Cranston RW, Inkley FA (1957) The determination of pore structures from nitrogen adsorption isotherms. Adv Catal 9:143-154. https://doi.org/10.1016/S0360-0564(08)60163-7

20. Čižmek A, Komunjer L, Subotić B, Široki M, Rončević S (1992) Kinetics of zeolite dissolution: part 3. Dissolution of synthetic mordenite in hot sodium solutions. Zeolites 12:190-196. https ://doi.org/10.1016/0144-2449(92)90083-2

21. Cundy CS, Cox PA (2003) The hydrothermal synthesis of zeolites: history and development from the earlier days to the present time. Chem Rev 103:663-701. https://doi.org/10.1021/cr020060i

22. Groen JC, Jansen JC, Moulijn JA, Pérez-Ramírez J (2004) Optimal aluminum-assisted mesoporosity development in MFI zeolites by desilication. J Phys Chem B 108:13062-13065. https://doi. org/10.1021/jp047194f

23. Mirchell S, Michels N-L, Kunze K, Pérez-Ramírez J (2012) Visualization of hierarchically structured zeolite bodies from macro to nano length scales. Nat Chem 4:825-831. https://doi. org/10.1038/nchem.1403

24. Van Donk S, Janseen AH, Bitter JH, De Jong KP (2003) Generation, characterization, and impact of mesopores in zeolite catalysts. Catal Rev Sci Eng 45:297-319. https://doi.org/10.1081/ CR-120023908

25. Zhai D, Zhao L, Liu Y, Xu J, Shen B, Gao J (2015) Dissolution and absorption: a molecular mechanism of mesopore formation in alkaline treatment of zeolite. Chem Mater 27:67-74. https://doi. org/10.1021/cm503151k

26. Maeda H, Kurosaki Y, Nakamura T, Nakayama M, Ishida EH, Kasuga T (2014) Control of chemical composition of hydrogrossular prepared by hydrothermal reaction. Mater Lett 131:132-134. https://doi.org/10.1016/j.matlet.2014.05.168

27. Li D, Li K, Xu R, Zhu X, Wei Y, Tian D, Cheng X, Wang H (2019) Enhanced $\mathrm{CH}_{4}$ and $\mathrm{CO}$ oxidation over $\mathrm{Ce}_{1-\mathrm{x}} \mathrm{Fe}_{x} \mathrm{O}_{2-\delta}$ hybrid catalysts by tuning the lattice distortion and the state of surface iron species. ACS Appl Mater Interf 11:19227-19241. https://doi. org/10.1021/acsami.9b05409

28. Williamson GK, Hall WH (1953) X-ray line broadening from filed aluminium and wolfram. Acta Metall 1:22-31. https://doi. org/10.1016/0001-6160(53)90006-6

29. Shi $Y, H u H$, Ren H (2020) Dissolved organic matter (DOM) removal from biotreated coking wastewater by chitosanmodified biochar: adsorption fractions and mechanisms. Bioresour Technol 297:122281. https://doi.org/10.1016/j.biort ech.2019.122281

30. Truong HB, Ike IA, Ok YS, Hur J (2020) Polyethyleneimine modification of activated fly ash and biochar for enhanced removal of natural organic matter from water via adsorption. Chemosphere 243:125454. https://doi.org/10.1016/j.chemosphere.2019.12545 4

31. Beiki S, Hassani AH, Panahi HA (2019) Preparation and characterization of magnetite modified nanoparticles with $p$-benzoquinone-ethylenediamine for adsorption of humic acid from aqueous solution. Desal Water Treat 158:266-279. https://doi. org/10.5004/dwt.2019.24240

32. Suchanek M, Niewiara E, Wilkosz K, Kubiak WW (2019) Nanopowders of yttria-stabilized zirconia doped with rare earth elements as adsorbents of humic acid. Materials 12:3915. https:// doi.org/10.3390/ma12233915

33. Gouttal K, Benghalem A, Mimanne G, Karim B (2018) Removal of organic matter from wastewater using M/Al-pillared clays $(\mathrm{M}=\mathrm{Fe}$ or $\mathrm{Mn})$ as coagulants. Water Sci Technol 78:534-544. https://doi.org/10.2166/wst.2018.321

34. dos Reis GS, Cazacliu BG, Correa CR, Ovsyannikova E, Kruse A, Sampaio CH, Lima EC, Dotto GL (2020) Adsorption and recovery of phosphate from aqueous solution by the construction and demolition wastes sludge and its potential use as phosphatebased fertiliser. J Environ Chem Eng 8:103605. https://doi. org/10.1016/j.jece.2019.103605

35. dos Reis GS, Thue PS, Cazacliu BG, Lima EC, Sampaio CH, Quattrone M, Ovsyannikova E, Kruse A, Dotto GL (2020) Effect of concrete carbonation on phosphate removal through adsorption process and its potential application as fertilizer. J Clean Prod 256:120416. https://doi.org/10.1016/j.jclepro.2020.120416

Publisher's Note Springer Nature remains neutral with regard to jurisdictional claims in published maps and institutional affiliations. 